\title{
GEOCHEMISTRY AND MINERALOGY OF ICE-DAMMED LAKE SEDIMENTS OF THE LĘBORK DEPOSIT
}

\author{
RadosŁaw Rogoziński* (iD) AND Alina MacieJewSKa \\ ${ }^{1}$ Faculty of Geodesy and Cartography, Department of Spatial Planning and Environmental Sciences, Warsaw University of Technology, \\ Politechniki 1 sq., room 337, 00-661 Warsaw, Poland
}

\begin{abstract}
Varved clay deposits from ice-dammed lakes are a particularly important and broadly applied raw material used for the production of high-quality ceramics (red bricks, roof tiles, etc.), but the mineralogy and geochemistry of these sediments are not fully understood. The aim of the present study was to determine the chemical and mineralogical composition of ice-dammed lake sediments of the Lębork deposit. Major-element analysis of the compositions of selected samples from the ice-dammed lake clays was performed by X-ray fluorescence (XRF) and trace elements were determined by inductively coupled plasma-mass spectrometry. The mineralogical composition of clay samples was determined by X-ray diffraction (XRD). Analyses of the chemical composition of the ice-dammed lake clays of the Lębork deposit showed that the dominant component was $\mathrm{SiO}_{2}$ with a mean content of 56.13 wt.\%; the second most abundant component was $\mathrm{Al}_{2} \mathrm{O}_{3}$, with a mean content for the entire deposit of $11.61 \mathrm{wt} . \%$. Analysis by ICP-MS indicated the presence of rare earth elements (REE), e.g. cerium, neodymium, lanthanum, and praseodymium; their mean contents are: 56.9, 27.0, 26.3, and 7.3 ppm, respectively. Mineralogical analysis of the varved clays identified quartz, muscovite, calcite, and clay minerals - illite, kaolinite, and montmorillonite. The material filling the Lębork basin is characterized by small lateral and vertical variability in chemical composition. The results of the present study may be of considerable importance in determining the parent igneous, metamorphic, and sedimentary rocks, the weathering products of which supplied material to the ice-dammed lake, as well as in determining the mechanisms and character of the sedimentation process itself.
\end{abstract}

Keywords - Clay minerals $\cdot$ Geochemistry $\cdot$ Ice-dammed lake sediments $\cdot$ Mineralogy $\cdot$ Varved clays

\section{INTRODUCTION}

Pleistocene extraglacial ice-dammed lakes were formed as a result of ice-barring of a river valley and damming up the river flowing toward the ice-dam. Clay-silty varves formed in such lakes are distinctive glacial features, due to the rhythmic sequence of deposition of sediments over a single year and are useful for Pleistocene stratigraphy. The method known as "varve chronology" was invented in Sweden (de Geer 1912) and has been applied successfully in many areas around the world.

The Lębork ice-dammed lake provides an example of sedimentation in an extensive basin developed at an ice-sheet terminus. Ice-dammed lake sediment deposits develop in water bodies formed through the inhibition of runoff and damming waters flowing through the ice sheet terminus. They are lithologically distinctive and characterized by a sequence of facies, from fluvioglacial sands through glaciolimnic deposits, to icedammed lake rhythmites (Paluszkiewicz 2004).

Rhythmically stratified (varved) series are sediments characteristic and diagnostic of glaciolimnic environments. The Lębork ice-dammed lake sequence was developed in the course of cyclical sedimentation defined as the development of deposits with systematic sequence of one or more facies, designated as the $\mathrm{AB}$ sequence. Such a sequence develops in the course of a single sedimentation cycle described as a cyclothem (Karnkowski 1993).

\footnotetext{
* E-mail address of corresponding author: radoslaw. rogozinski@pw.edu.pl
}

DOI: $10.1007 / \mathrm{s} 42860-021-00129-6$
The term varve was defined by de Geer (1912), the creator of the varvochronological concept, as a periodically repeating pattern of layers of mineral series, rhythmically stratified, with dark and light laminae, differing in geochemical and granulometric composition, developed in the course of a single sedimentation cycle (De Geer 1912). The material in the dark laminae has an homogeneous mineralogical composition of the finest clay fractions that persisted in suspension for a long time. Deposition occurred slowly, in the winter period under the ice cover, with an absence of coarser fractions from proglacial waters. The laminae thus developed are thin, dark clay layers. Light 'summer' laminae developed in the course of deposition during the summer season. The supply of the coarser fraction of mineral grains from ice ablation is considerably more intensive during that time. Particles of sandy and silty fractions are deposited much more quickly, developing light laminae which are thicker than 'winter' laminae, with variable mineralogical and granulometric composition. Considering single-cycle - light 'summer' and dark 'winter' laminae - de Geer (1912) determined that they correspond to the annual sedimentation cycle. Such an assumption permits absolute dating of varved deposits. This geochronological method was called the Swedish timescale.

The supply of material and the process of development of rhythmites in glaciolimnic basins are determined primarily by allocyclical processes related to external conditions (e.g. climate, current weather, rate of glacier ablation, volume of material supplied to the basin, etc.), and to a lesser extent by autocyclical processes (precipitation of mineral compounds, development of living organisms, activity of density currents (Karnkowski 1993)). 


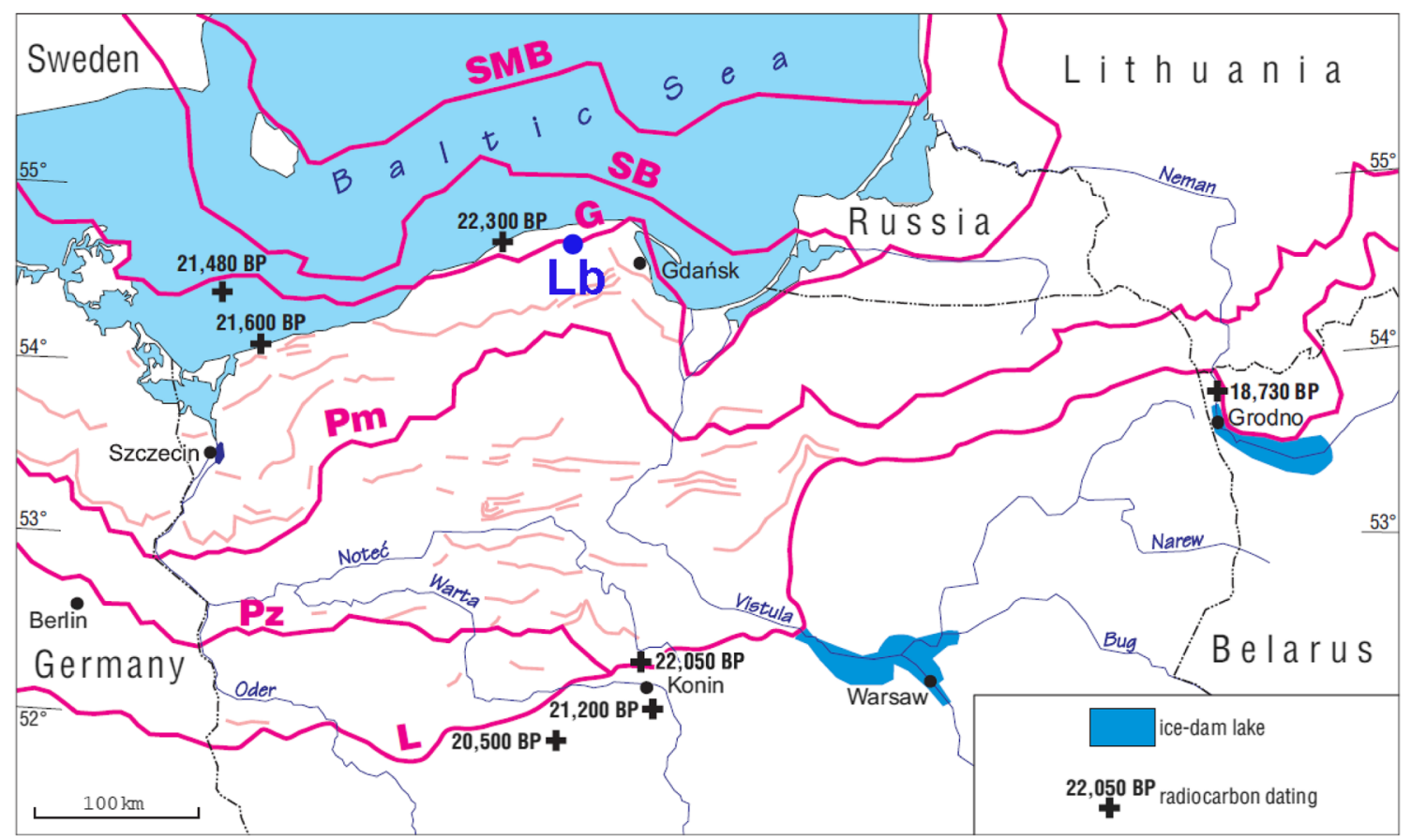

Fig. 1 Location of the Lębork ice-dammed lake (Lb), during the Late Vistulian in Poland, and neighboring areas. The figure was compiled from a number of previous studies. Selected, non-calibrated radiocarbon dates are shown. Ice sheet limits: L — Leszno (Brandenburg) Phase, Pz Poznań (Frankfurt) Phase, Pm — Pomeranian Phase, G — Gardno Phase, SB — Słupsk Bank Phase, SMB — Southern Middle Bank Phase. Also indicated are limits of minor local glacial oscillations and proglacial lakes in the Middle Vistula and Middle Neman valleys (after Marks 2005, modified)

Two basic hypotheses exist in terms of the genesis and formation of fluvioglacial deposits - gravitational and turbiditic (Bakhmutov et al. 2008). According to Antevs (1951), deposition of summer varved laminae occurs as a result of the accumulation of silts after summer flooding of proglacial waters, and winter laminae, in the form of clays, occur as a result of the process of deposition from suspension under ice cover. Other authors defined varves as deposits developed as a result of seasonal activity of bottom currents or their specific type, namely "turbidity currents" (Kuenen 1951). Typical "classic" varves defined by Sturm (1979) seem to be characterized by sharp boundaries between laminae and with a lack of gradation typical of the Bouma sequence; these are a result of the process of deposition of material from suspension and outside the range of activity of underflows from different zones of thermal convection of water and "interflow currents" (Sturm 1979).

Varves are usually relatively thin, $0.5-5.0 \mathrm{~cm}$, although light laminae are usually somewhat thicker. Light laminae which are much thicker, up to several $\mathrm{cm}$, are also encountered, however. They commonly feature visible second-order laminae with a varved character. The second-order laminae are usually interpreted as daily or diurnal varves, or as repeatedly stratified aggradation silts developed by underflows. Inflow does not have to be constant over a single deposition season; it can also be related to daily ablation and weather changes. The ablation and changes in weather can indicate a variable supply of transported material. Light laminae are, therefore, considered to be the deposit of a single sedimentation cycle which can be developed over the course of many such cycles of a smaller order. The term "interseasonal laminae" seems more suitable for describing this type of multilayer deposit (Vyahirev 1997).

Varves considered to be deposits of annual sedimentation do not necessarily have to reflect deposition occurring over the entire year. This results in the problem of interpretation of varves as an accurate geochronological method.

According to Merta (1978), changes in the thickness of particular varves could be related to the width of the sedimentary basin and not just to climate change, e.g. a rapid change in varve thickness could be the result of rapid change in the width of the depositional area, an over-flooded, terrace-shaped river valley.

A detailed sedimentological analysis of glaciolimnic formations, based on the example of the Warsaw ice-dammed lake, was presented by Merta (1978) who designated the type of extraglacial ice-dammed lakes, simultaneously suggesting that it is dominant throughout the area of the Polish Lowland.

Varved deposit series are usually deposited horizontally in accordance with the terrain unevenness and inclination (Paluszkiewicz 2004, following Krygowski 1934). As in other depositional environments, syn- and post-sedimentary deformation processes can occur here. The development of runoff disturbances may be caused by an inclination as small as $1^{\circ}$ (Peterss 1995); these are related to direct accumulation of sediment in various morphological conditions of the basin 


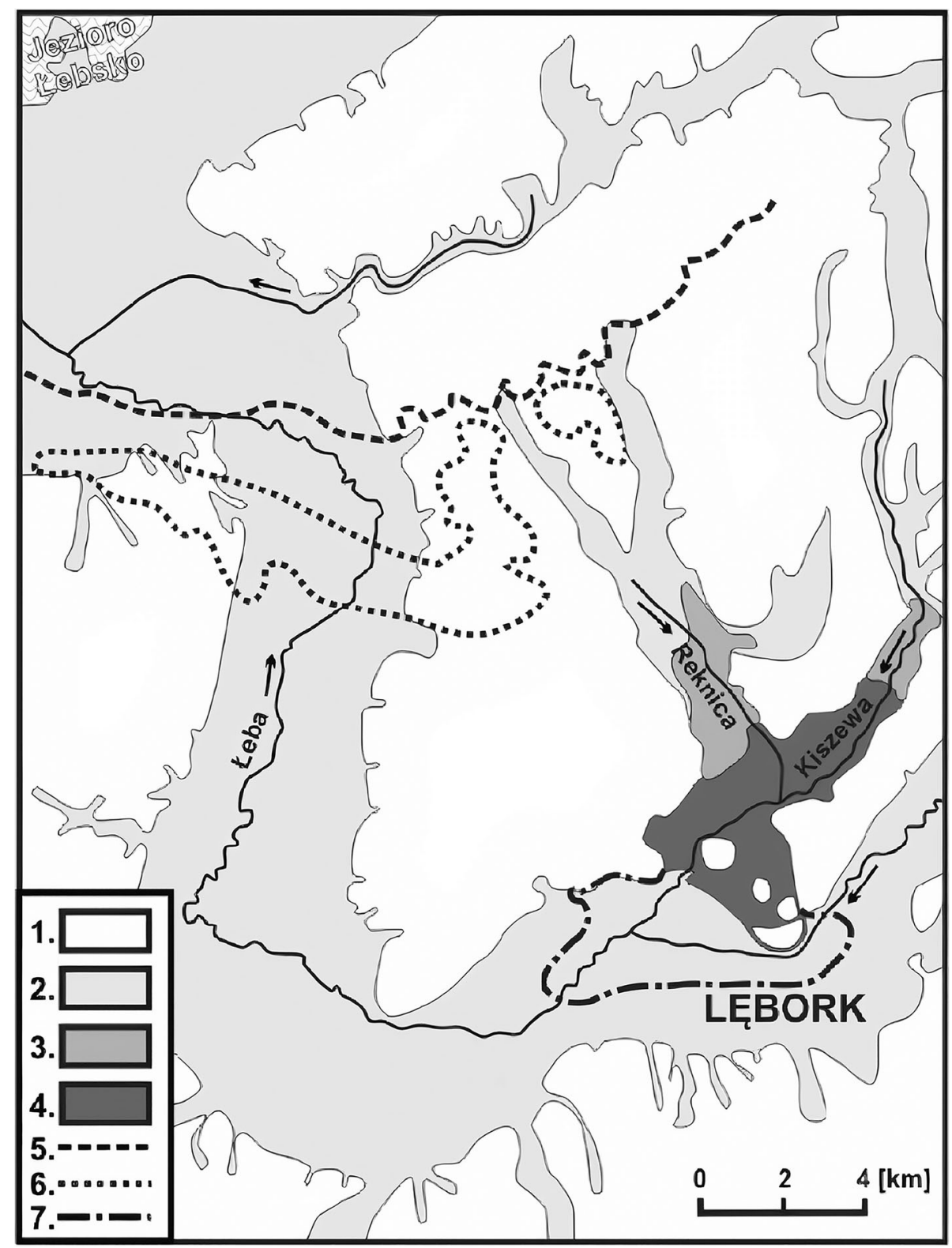

Fig. 2 Range of the Lębork ice-dammed lake (source: Morawski 1989; simplified). Explanation: 1 - moraine areas; 2 - bottoms of river valleys and the Leba ice-marginal valley; 3 - silts of the Lębork ice-dammed lake; 4 - clays of the Lębork ice-dammed lake; 5 - position of the ice-sheet terminus during the existence of the Lębork ice-dammed lake; 6 - areas of dead ice during the existence of the Lębork ice-dammed lake; 7 maximum range of the ice-dammed lake before the erosion of clayey deposits in the bottom of the Łeba ice-marginal valley (data from, among others, Piątkowski 1960; Morawski 1989, 1990)

bottom, with deposition resulting from the activity of density currents or melting of rooted patches of dead ice.

The most frequent occurrence of ice-dammed lake sedimentation is observed in northern Poland in the Pomeranian Region, in marginal zones of the Pomeranian phase of the Vistula glaciation.

The purpose of the present study was to determine the geochemical and mineralogical composition of the Lębork sediments and their lateral and vertical variability. These results will allow the sedimentation process to be characterized and for the sediment supply over the $\sim 2000$ y of existence of the ice-dammed Lębork lake to be understood.

\section{Characteristics of the Study Area}

Deposits filling the Leebork ice-dammed lake, the so-called "Lębork clays" (Piątkowski 1960; Morawski 1989, 1991), are an example of the sedimentation record of an extensive, icedammed lake developed at the ice-sheet terminus. The lake was located in northern Poland (Fig. 1), in the Leba and Reda 

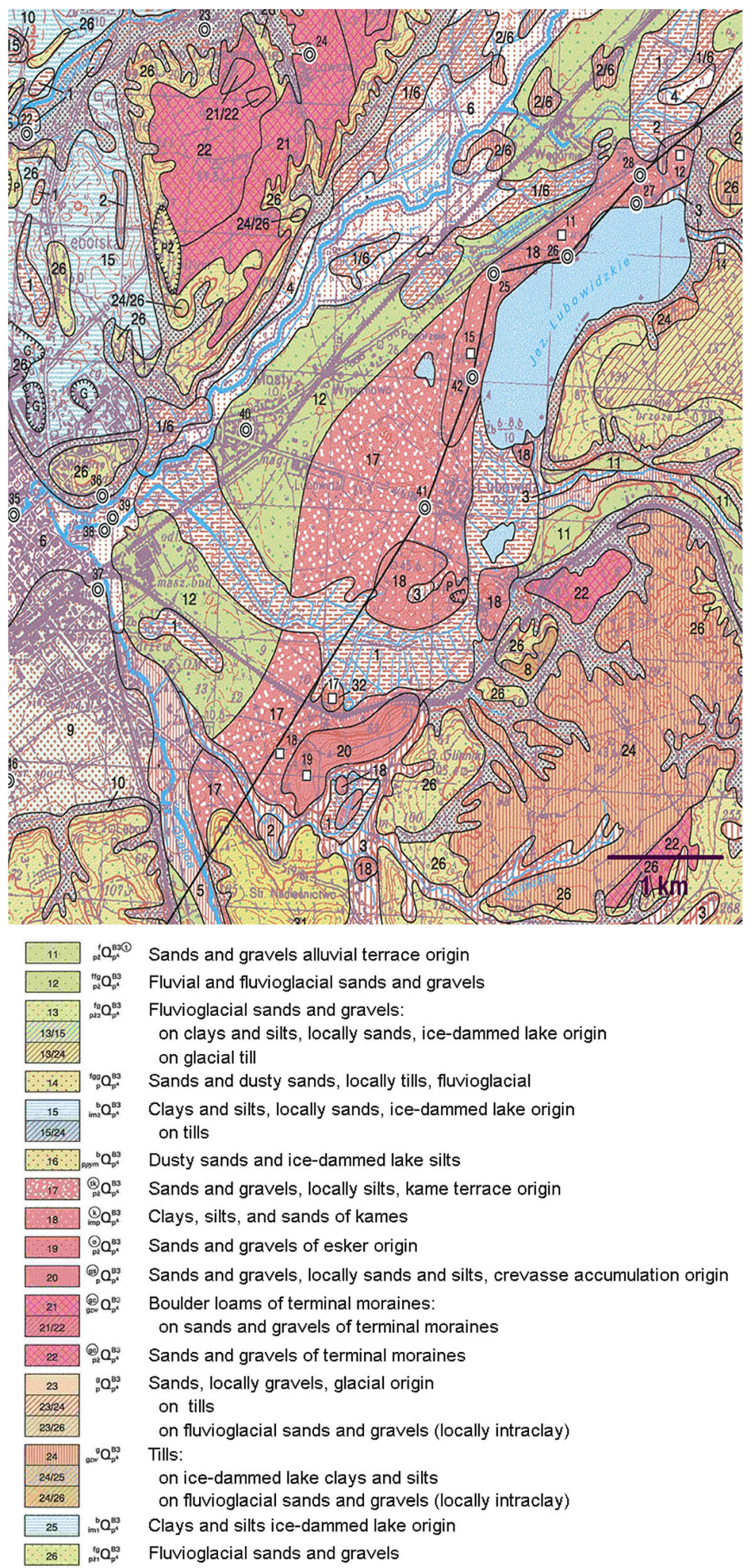

Fig. 3 Fragment of the detailed geological map at a scale of 1:50,000 (15 (west of the lake) - ice-dammed lake clay deposits) (source: Zaleszkiewicz 2005 sheet 13 Łęczyce, N-33-60-B, PGI) 
Table 1 Stratigraphic table for the Late Pleistocene and Early Holocene

\begin{tabular}{|c|c|c|c|c|}
\hline 1. GLACIAL & $\begin{array}{l}\text { 2nd (OIS) } \\
\text { 3rd Oxygen isotope } \\
\text { stages }\end{array}$ & DATE & STADIAL & PHASES \\
\hline HOLOCENE & 1 & $10,250-\ldots \mathrm{BP}$ & Holocene & $\begin{array}{l}\text { Subatlantic } 2,800-\ldots \text { BP } \\
\text { Subboreal } 5,000-2,800 \mathrm{BP} \\
\text { Atlantic } 8,400-5,000 \mathrm{BP} \\
\text { Boreal } 9,300-3,400 \mathrm{BP} \\
\text { Preboreal } 10,250-9,300 \mathrm{BP}\end{array}$ \\
\hline \multirow[t]{8}{*}{$\begin{array}{l}\text { G.WISŁY (Weichselian } \\
\text { glaciation) }\end{array}$} & 2 & $\begin{array}{l}30,000-10,250 \\
\text { BP }\end{array}$ & $\begin{array}{l}\text { Late glacial } \\
14,000-10,300 \\
\text { BP }\end{array}$ & $\begin{array}{l}\text { Dryas III 10,700-10,250 BP } \\
\text { Allerod 11,800-10,700 BP } \\
\text { Dryas II 12,000-11,800 BP } \\
\text { Bolling } 13,000-12,000 \mathrm{BP}\end{array}$ \\
\hline & & & Main stadial & $\begin{array}{l}\text { Dryas I } 14,000-13,000 \mathrm{BP} \\
\text { Epe (interphase Pre-bolling) } \\
\quad 15,000-14,000 \mathrm{BP} \\
\text { Gardna } 15,000-14,500 \mathrm{BP} \\
\text { pomorska } 17,000-15,000 \mathrm{BP} \\
\text { Poznańska } 20,000-17,000 \mathrm{BP} \\
\text { Leszczyńska } 30,000-20,000 \mathrm{BP}\end{array}$ \\
\hline & 3 & $\begin{array}{l}57,000---30,000 \\
\quad \text { BP }\end{array}$ & $\begin{array}{l}\text { Grudziądz } \\
\text { interstadial }\end{array}$ & $\begin{array}{l}\text { interphase Denekamp about 30,000 BP } \\
\text { phase [including interphase Arcy. } \\
\text { Stillfried] } \\
\text { interphase Hengeloo 43,000 BP } \\
\text { interphase Moershoofd 45,000 BP } \\
\text { phase } \\
\text { interphase Glinde 50,000BP } \\
\text { phase } \\
\text { interphase Oerel about 57,000 BP }\end{array}$ \\
\hline & 4 & $\begin{array}{l}72,000-57,000 \\
\text { BP }\end{array}$ & Świecie & phase \\
\hline & $5 \mathrm{a}$ & $\begin{array}{l}83,000-72,000 \\
\quad \mathrm{BP}\end{array}$ & Gniew & $\begin{array}{l}\text { interphase Odderade } \\
\text { Vistulian } 2 \\
\text { interphase Braru /Radunki [Brorup } \\
\quad \text { sensu largo] }\end{array}$ \\
\hline & $5 b$ & $\begin{array}{l}96,000-83,000 \\
\text { BP }\end{array}$ & Toruń & Toruń [Intra Brorup sensu largo] \\
\hline & $5 \mathrm{c}$ & $\begin{array}{l}105,000-96,000 \\
\text { BP }\end{array}$ & & $\begin{array}{l}\text { interphase Amersfoort /Knibawy } \\
\text { [Brorup sensu largo] }\end{array}$ \\
\hline & $5 d$ & $\begin{array}{l}111,000-105,000 \\
\text { BP }\end{array}$ & & Malbork [Vistulian 1] \\
\hline
\end{tabular}

Italic indicates the period analysed in the present study (late glacial source: Richling and Ostaszewska 2005, modified)

ice-marginal valley. This mesoregion is a part of the Koszalin Coastal Area (Kondracki 2000). The existence of the icedammed lake is related to the last occurrence of the Fennoscandian Ice Sheet in the territory of Poland (Stroeven et al. 2016) during the Gardno phase of the Vistula glaciation. The Lębork ice-dammed lake developed within the Łeba icemarginal valley, 10-12 km southeast of the ice-sheet terminus during its retreat toward the Gardzieńsko-Lebska Lowland (Morawski 1991), when the main water outflow from the front of the ice-sheet terminus was to the west. Moreover, the ice- dammed lake was fed by smaller rivers: the Reknica channel from the north, and through the Kiszewa channel from the northeast (Fig. 2).

Horizons of sands deposited previously occurred west of the ice-dammed lake, blocking water outflow through the bottom of the Łeba ice-marginal valley. In the central part of the basin (with a surface area of $\sim 25 \mathrm{~km}^{2}$ ), the finest clay material was deposited, whereas silts and sands were deposited in the bottoms of the tributary channels. The geological structure of the study area is presented in Fig. 3. 


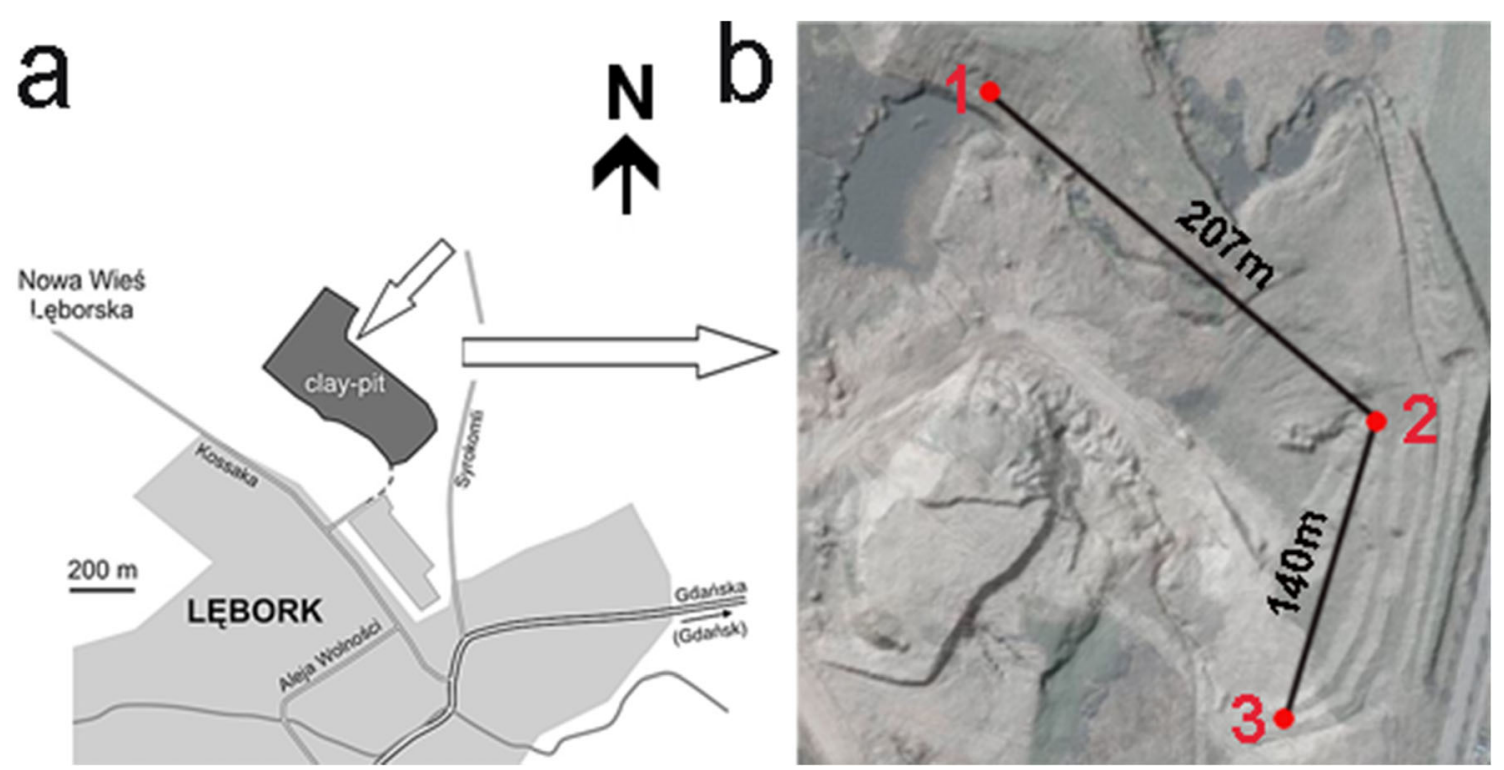

Fig. 4 a Location of the clay pit and b sampling sites within the clay pit - combination of orthophotomap and LIDAR (light detection and ranging), distances $(\mathrm{m})$ between sampling sites are indicated. 1 - location 1, 2 - location 2, 3 - location 3 (sources: Gedl 2011; and https://mapy. geoportal.gov.pl/, modified)

The remains of the ice-dammed lake are varved laminae of clays and silty-sandy deposits (Fig. 5) reaching a maximum thickness of $14 \mathrm{~m}$ (Zaleszkiewicz 2005) to $16 \mathrm{~m}$ (Morawski 1990). The ages of the varves were determined by means of the thermoluminescence method (TL, measurement error $\pm 1.5-2.5 \mathrm{y}$ ) for fine sand deposits underlying clays directly. These had an age of $14 \mathrm{ky}$; silty laminae in the uppermost layer of varved clays had an age of $13 \mathrm{ky}$; locally occurring overlying sands were dated at $11 \mathrm{ky}$ (Morawski 1989, 1990, Table 1).

The clay deposits filling the basin are of considerable practical importance as raw material for the production of ceramics for construction. They are excavated on an industrial scale from an extensive excavation wall in Lęork, providing raw material for a large ceramics production plant (currently Wienenberger).

Documentation of the deposit recorded up to the $1980 \mathrm{~s}$ (Morawski 1990) estimated the volume of the varved clays to be $4384 \mathrm{~m}^{3}$ in the Lęork deposit, and $8442 \mathrm{~m}^{3}$ in the Nowa Wieś Lęorska deposit within the same ice-dammed lake.

\section{MATERIALS AND METHODS}

\section{Sampling Methods}

Samples were collected from three different sites in the Wienenberger clay pit (Fig. 4), and from three different levels within the pit - roof, middle, and bottom (Fig. 5). A total of nine samples was collected.

Samples of ice-dammed lake clay sediments collected in the field, weighing from $\sim 200 \mathrm{~g}$ to $300 \mathrm{~g}$, contained both light (summer) and dark (winter) laminae. Air-dried samples were ground in an agate mortar (to avoid potential contamination by metals) to the grain size required by analytical laboratories. Light and dark laminae were mixed together.

\section{Laboratory Methods}

The chemical compositions of selected samples of icedammed lake clays were determined at the laboratory of the Institute of Glass and Building Materials in Gliwice, Poland, by means of wavelength dispersive X-ray florescence spectrometry, with ignition of samples at a temper-

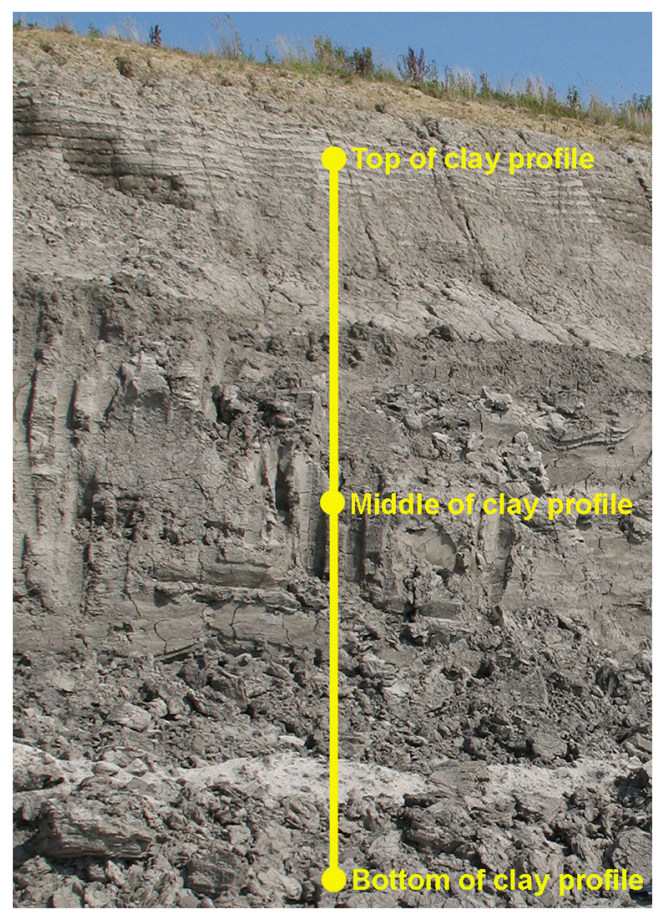

Fig. 5 Sampling profiles of the Lebork deposit for the purposes of chemical analysis 
Table 2 Chemical compositions of ice-dammed lake clays from the Lębork deposit (wt.\%)

\begin{tabular}{|c|c|c|c|c|c|c|c|c|c|}
\hline \multirow[t]{2}{*}{ Component } & \multicolumn{3}{|c|}{ Location 1} & \multicolumn{3}{|c|}{ Location 2} & \multicolumn{3}{|c|}{ Location 3} \\
\hline & Bottom & Middle & Top & Bottom & Middle & Top & Bottom & Middle & Top \\
\hline Loss on ignition at a temperature of $1025^{\circ} \mathrm{C}$ & 14.47 & 9.56 & 9.16 & 12.36 & 10.35 & 12.51 & 11.07 & 11.99 & 10.63 \\
\hline $\mathrm{SiO}_{2}$ & 53.63 & 60.74 & 59.14 & 54.45 & 59.09 & 51.47 & 56.07 & 52.64 & 57.95 \\
\hline $\mathrm{Al}_{2} \mathrm{O}_{3}$ & 11.78 & 11.28 & 12.39 & 11.31 & 10.41 & 12.38 & 11.44 & 12.56 & 10.98 \\
\hline $\mathrm{CaO}$ & 7.91 & 6.91 & 6.11 & 9.82 & 8.39 & 9.59 & 8.75 & 9.00 & 8.44 \\
\hline $\mathrm{Fe}_{2} \mathrm{O}_{3}$ & 5.09 & 4.84 & 5.87 & 4.54 & 4.72 & 6.42 & 5.33 & 6.22 & 4.98 \\
\hline $\mathrm{MgO}$ & 2.75 & 2.36 & 2.26 & 3.09 & 2.58 & 2.99 & 2.78 & 2.93 & 2.68 \\
\hline $\mathrm{K}_{2} \mathrm{O}$ & 3.06 & 2.94 & 3.20 & 3.08 & 2.87 & 3.21 & 3.02 & 3.23 & 2.93 \\
\hline $\mathrm{TiO}_{2}$ & 0.62 & 0.60 & 0.67 & 0.64 & 0.64 & 0.69 & 0.66 & 0.69 & 0.67 \\
\hline $\mathrm{Na}_{2} \mathrm{O}$ & 0.56 & 0.64 & 0.51 & 0.56 & 0.80 & 0.56 & 0.70 & 0.53 & 0.57 \\
\hline
\end{tabular}

Table 3 Statistical parameters of the primary components of ice-dammed lake clays

\begin{tabular}{lcccccc}
\hline $1 \mathrm{st}$ & $\begin{array}{l}\text { Arithmetic mean } \\
\text { (wt.\%) }\end{array}$ & $\begin{array}{l}\text { Geometric mean } \\
(\text { wt.\%) }\end{array}$ & $\begin{array}{l}\text { Median } \\
\text { (wt.\%) }\end{array}$ & $\begin{array}{l}\text { Minimum } \\
\text { (wt.\%) }\end{array}$ & $\begin{array}{l}\text { Maximum } \\
\text { (wt.\%) }\end{array}$ & $\begin{array}{l}\text { Standard deviation } \\
\text { (wt.\%) }\end{array}$ \\
\hline $\mathrm{SiO}_{2}$ & 56.13 & 56.05 & 56.07 & 51.47 & 60.74 & 3.27 \\
$\mathrm{Al}_{2} \mathrm{O}_{3}$ & 11.61 & 11.59 & 11.44 & 10.41 & 12.56 & 0.72 \\
$\mathrm{CaO}$ & 8.32 & 8.24 & 8.44 & 6.11 & 9.82 & 1.20 \\
$\mathrm{Fe}_{2} \mathrm{O}_{3}$ & 5.33 & 5.30 & 5.09 & 4.54 & 6.42 & 0.68 \\
$\mathrm{MgO}$ & 2.71 & 2.70 & 2.75 & 2.26 & 3.09 & 0.28 \\
$\mathrm{~K}_{2} \mathrm{O}$ & 3.06 & 3.06 & 3.06 & 2.87 & 3.23 & 0.13 \\
$\mathrm{TiO}_{2}$ & 0.65 & 0.65 & 0.66 & 0.60 & 0.69 & 0.03 \\
$\mathrm{Na}_{2} \mathrm{O}$ & 0.60 & 0.60 & 0.56 & 0.51 & 0.80 & 0.09 \\
\hline
\end{tabular}

ature of $1025^{\circ} \mathrm{C}$, using a MagiX Panalytical spectrometer (PANalytical B.V., Almelo, The Netherlands). Determination of trace elements by ICP-MS and Aqua regia-ICP methods was performed at the Laboratory of Geochemical-Mineralogical Analyses, GeoAnaliza, Poland. Measurements were carried out using an Elan 5000 instrument from Perkin Elmer (SCIEX, Wellesley, Massachusetts, USA).

Analyses of the mineralogical composition of samples of ice-dammed lake clays were performed using an X-ray powder diffractometer (Bruker D2 Phaser, Bruker AXS GmbH, Karlsruhe, Germany).

The weight of individual ground samples used for analysis varied from 5.5 to $7.5 \mathrm{~g}$, in accordance with the requirements of the analytical laboratory. The method of sampling and the sample preparation allowed determination of the average contents of compounds and chemical elements in the batches analysed, as well as tracing potential changes in chemical composition through the stratigraphic profile - from the oldest deposits at the bottom to the youngest in the uppermost layer.

Table 4 Matrix of correlation coefficients; correlations of $>|0.7|$ are shown in italic

\begin{tabular}{lllllllll}
\hline & $\mathrm{SiO}_{2}$ & $\mathrm{Al}_{2} \mathrm{O}_{3}$ & $\mathrm{CaO}$ & $\mathrm{Fe}_{2} \mathrm{O}_{3}$ & $\mathrm{MgO}$ & $\mathrm{K}_{2} \mathrm{O}$ & $\mathrm{TiO}_{2}$ & $\mathrm{Na}_{2} \mathrm{O}$ \\
\hline $\mathrm{SiO}_{2}$ & 1.00 & -0.56 & -0.72 & -0.53 & -0.86 & -0.65 & -0.49 & 0.43 \\
$\mathrm{Al}_{2} \mathrm{O}_{3}$ & -0.56 & 1.00 & -0.06 & 0.87 & 0.15 & 0.96 & 0.54 & -0.76 \\
$\mathrm{CaO}$ & -0.72 & -0.06 & 1.00 & 0.05 & 0.96 & 0.12 & 0.36 & 0.06 \\
$\mathrm{Fe}_{2} \mathrm{O}_{3}$ & -0.53 & 0.87 & 0.05 & 1.00 & 0.14 & 0.83 & 0.77 & -0.48 \\
$\mathrm{MgO}$ & -0.86 & 0.15 & 0.96 & 0.14 & 1.00 & 0.31 & 0.36 & -0.17 \\
$\mathrm{~K}_{2} \mathrm{O}$ & -0.65 & 0.96 & 0.12 & 0.83 & 0.31 & 1.00 & 0.62 & -0.75 \\
$\mathrm{TiO}_{2}$ & -0.49 & 0.54 & 0.36 & 0.77 & 0.36 & 0.62 & 1.00 & -0.36 \\
$\mathrm{Na}_{2} \mathrm{O}$ & 0.43 & -0.76 & 0.06 & -0.48 & -0.17 & -0.75 & -0.36 & 1.00 \\
\hline
\end{tabular}


Table 5 Contents of significant elements in the Lębork deposit

\begin{tabular}{|c|c|c|c|c|c|c|c|c|c|c|c|c|}
\hline \multirow[t]{2}{*}{ Element } & \multirow[t]{2}{*}{ Units } & \multirow{2}{*}{$\begin{array}{l}\text { Detection } \\
\text { threshold }\end{array}$} & \multirow[t]{2}{*}{ Method of analysis } & \multicolumn{3}{|c|}{ Location 1} & \multicolumn{3}{|c|}{ Location 2} & \multicolumn{3}{|c|}{ Location 3} \\
\hline & & & & Bottom & Middle & Top & Bottom & Middle & Top & Bottom & Middle & Top \\
\hline $\mathrm{Li}$ & ppm & 0.1 & AR-MS & 45.2 & 38.0 & 37.2 & 41.7 & 38.7 & 37.2 & 39.6 & 34.6 & 28.8 \\
\hline $\mathrm{Be}$ & ppm & 0.1 & AR-MS & 1.8 & 1.3 & 1.3 & 1.5 & 1.4 & 1.4 & 1.4 & 1.2 & 1.0 \\
\hline B & ppm & 1 & AR-MS & 58 & 50 & 48 & 57 & 55 & 49 & 53 & 44 & 31 \\
\hline $\mathrm{Na}$ & $\%$ & 0.001 & AR-MS & 0.036 & 0.029 & 0.032 & 0.04 & 0.034 & 0.037 & 0.038 & 0.035 & 0.031 \\
\hline $\mathrm{Mg}$ & $\%$ & 0.01 & AR-MS & 1.52 & 1.37 & 1.41 & 1.44 & 1.37 & 1.46 & 1.43 & 1.43 & 0.78 \\
\hline $\mathrm{Al}$ & $\%$ & 0.01 & AR-MS & 3.24 & 2.64 & 2.61 & 2.94 & 2.81 & 2.66 & 2.84 & 2.52 & 2.21 \\
\hline $\mathrm{P}$ & $\%$ & 0.001 & AR-ICP & 0.05 & 0.045 & 0.042 & 0.044 & 0.046 & 0.044 & 0.048 & 0.043 & 0.048 \\
\hline S & $\%$ & 0.001 & AR-ICP & 0.417 & 0.526 & 0.547 & 0.515 & 0.481 & 0.588 & 0.554 & 0.551 & 0.04 \\
\hline K & $\%$ & 0.01 & AR-MS & 0.95 & 0.79 & 0.75 & 0.88 & 0.85 & 0.79 & 0.83 & 0.71 & 0.53 \\
\hline $\mathrm{Ca}$ & $\%$ & 0.01 & AR-MS & 6.6 & 6.2 & 6.69 & 6.39 & 6.07 & 6.68 & 6.95 & 7.19 & 4.68 \\
\hline V & ppm & 1 & AR-MS & 77 & 66 & 64 & 70 & 69 & 64 & 68 & 58 & 54 \\
\hline $\mathrm{Cr}$ & ppm & 0.5 & AR-MS & 66.0 & 56.1 & 54.3 & 61.6 & 58.4 & 54.8 & 56.0 & 48.2 & 44.9 \\
\hline $\mathrm{Ti}$ & $\%$ & 0.01 & AR-ICP & 0.06 & 0.06 & 0.06 & 0.05 & 0.05 & 0.06 & 0.06 & 0.06 & 0.07 \\
\hline $\mathrm{Mn}$ & ppm & 1 & AR-MS & 561 & 494 & 502 & 519 & 476 & 551 & 540 & 551 & 512 \\
\hline $\mathrm{Fe}$ & $\%$ & 0.01 & AR-MS & 3.98 & 3.44 & 3.38 & 3.73 & 3.52 & 3.38 & 3.66 & 3.08 & 3.3 \\
\hline Co & $\mathrm{ppm}$ & 0.1 & AR-MS & 16.9 & 15 & 14.4 & 15.2 & 14.6 & 14.8 & 15.1 & 13.8 & 13.2 \\
\hline $\mathrm{Ni}$ & ppm & 0.1 & AR-MS & 51 & 43.7 & 44.2 & 46 & 44.1 & 45.2 & 46.3 & 41.7 & 39.4 \\
\hline $\mathrm{Cu}$ & ppm & 0.01 & AR-MS & 26 & 21.8 & 21.6 & 21.7 & 22.1 & 23.1 & 22.9 & 19.9 & 24.2 \\
\hline $\mathrm{Zn}$ & ppm & 0.1 & AR-MS & 88.5 & 75.9 & 73.2 & 78.6 & 77 & 79.5 & 78.7 & 69.7 & 74.8 \\
\hline $\mathrm{Ga}$ & ppm & 0.02 & AR-MS & 10.7 & 8.69 & 8.54 & 9.72 & 9.2 & 8.78 & 9.01 & 7.81 & 7.18 \\
\hline As & ppm & 0.1 & AR-MS & 7.4 & 8.2 & 7.1 & 8.5 & 8.2 & 9.3 & 9.7 & 11.9 & 11 \\
\hline $\mathrm{Se}$ & ppm & 0.1 & AR-MS & 0.9 & 0.8 & 0.7 & 0.7 & 0.7 & 0.9 & 0.7 & 0.7 & 0.6 \\
\hline $\mathrm{Rb}$ & $\mathrm{ppm}$ & 0.1 & AR-MS & 66.5 & 54.3 & 53.4 & 58.6 & 57.4 & 55.6 & 57.8 & 49.9 & 45.6 \\
\hline $\mathrm{Sr}$ & ppm & 0.5 & AR-MS & 163 & 151 & 149 & 184 & 161 & 152 & 171 & 164 & 108 \\
\hline Y & ppm & 0.01 & AR-MS & 20.1 & 17 & 17.8 & 17.3 & 17.5 & 18.3 & 18.4 & 17.2 & 20.9 \\
\hline $\mathrm{Zr}$ & ppm & 0.1 & AR-MS & 8.7 & 13.1 & 7.6 & 6.9 & 6.6 & 8.1 & 10 & 8.6 & 9.1 \\
\hline $\mathrm{Sc}$ & ppm & 0.1 & AR-MS & 9.1 & 7.7 & 7.5 & 8.2 & 7.9 & 7.7 & 7.9 & 6.9 & 6.5 \\
\hline $\operatorname{Pr}$ & ppm & 0.1 & AR-MS & 8.1 & 7 & 6.9 & 6.8 & 7.2 & 7.2 & 7.3 & 6.6 & 8.6 \\
\hline $\mathrm{Gd}$ & ppm & 0.1 & AR-MS & 5.2 & 4.4 & 4.4 & 4.3 & 4.6 & 4.6 & 4.6 & 4.2 & 5.5 \\
\hline Dy & ppm & 0.001 & AR-MS & 3.81 & 3.29 & 3.3 & 3.3 & 3.32 & 3.36 & 3.5 & 3.21 & 3.84 \\
\hline Ho & ppm & 0.1 & AR-MS & 0.7 & 0.6 & 0.6 & 0.6 & 0.6 & 0.6 & 0.7 & 0.6 & 0.7 \\
\hline Er & ppm & 0.1 & AR-MS & 1.8 & 1.6 & 1.6 & 1.5 & 1.6 & 1.7 & 1.7 & 1.6 & 1.8 \\
\hline $\mathrm{Tm}$ & ppm & 0.1 & AR-MS & 0.2 & 0.2 & 0.2 & 0.2 & 0.2 & 0.2 & 0.2 & 0.2 & 0.3 \\
\hline $\mathrm{Nb}$ & ppm & 0.1 & AR-MS & 0.3 & 0.3 & 0.2 & 0.2 & 0.2 & 0.3 & 0.3 & 0.3 & 0.1 \\
\hline Mo & ppm & 0.01 & AR-MS & 0.47 & 0.48 & 0.46 & 0.44 & 0.44 & 0.49 & 0.56 & 0.49 & 0.53 \\
\hline $\mathrm{Ag}$ & ppm & 0.002 & AR-MS & 0.042 & 0.037 & 0.037 & 0.045 & 0.041 & 0.047 & 0.046 & 0.034 & 0.061 \\
\hline $\mathrm{Cd}$ & ppm & 0.01 & AR-MS & 0.1 & 0.1 & 0.09 & 0.1 & 0.1 & 0.12 & 0.1 & 0.12 & 0.09 \\
\hline In & ppm & 0.02 & AR-MS & 0.05 & 0.05 & 0.05 & 0.05 & 0.05 & 0.05 & 0.05 & 0.04 & 0.04 \\
\hline $\mathrm{Sn}$ & ppm & 0.05 & AR-MS & 1.39 & 1.15 & 1.08 & 1.18 & 1.16 & 1.16 & 1.2 & 1.05 & 0.96 \\
\hline $\mathrm{Sb}$ & ppm & 0.02 & AR-MS & 0.29 & 1.02 & 0.47 & 0.37 & 0.38 & 1.66 & 0.45 & 6.31 & 0.5 \\
\hline Cs & ppm & 0.02 & AR-MS & 2.86 & 2.41 & 2.19 & 2.33 & 2.34 & 2.36 & 2.55 & 2.22 & 2.24 \\
\hline $\mathrm{Ba}$ & ppm & 0.5 & AR-MS & 135 & 119 & 121 & 120 & 122 & 113 & 128 & 134 & 133 \\
\hline $\mathrm{La}$ & ppm & 0.5 & AR-MS & 29.7 & 24.9 & 24.8 & 24.5 & 25.6 & 25.8 & 26.6 & 23.7 & 31.4 \\
\hline $\mathrm{Ce}$ & ppm & 0.01 & AR-MS & 63.6 & 54.9 & 54.7 & 53.8 & 56.3 & 56.6 & 57.2 & 52.1 & 63.1 \\
\hline $\mathrm{Nd}$ & ppm & 0.02 & AR-MS & 29.8 & 26.0 & 25.3 & 25.4 & 26.4 & 26.7 & 26.8 & 24.7 & 31.7 \\
\hline $\mathrm{Sm}$ & $\mathrm{ppm}$ & 0.1 & AR-MS & 5.8 & 5.2 & 5.0 & 5.0 & 5.2 & 5.2 & 5.3 & 5.0 & 6.3 \\
\hline
\end{tabular}


Table 5 (continued)

\begin{tabular}{|c|c|c|c|c|c|c|c|c|c|c|c|c|}
\hline \multirow[t]{2}{*}{ Element } & \multirow[t]{2}{*}{ Units } & \multirow{2}{*}{$\begin{array}{l}\text { Detection } \\
\text { threshold }\end{array}$} & \multirow[t]{2}{*}{ Method of analysis } & \multicolumn{3}{|c|}{ Location 1} & \multicolumn{3}{|c|}{ Location 2} & \multicolumn{3}{|c|}{ Location 3} \\
\hline & & & & Bottom & Middle & Top & Bottom & Middle & Top & Bottom & Middle & Top \\
\hline $\mathrm{Eu}$ & ppm & 0.1 & AR-MS & 1.0 & 0.9 & 0.9 & 0.9 & 0.9 & 0.9 & 0.9 & 0.9 & 1.1 \\
\hline $\mathrm{Tb}$ & ppm & 0.1 & AR-MS & 0.7 & 0.6 & 0.6 & 0.6 & 0.6 & 0.6 & 0.6 & 0.6 & 0.7 \\
\hline $\mathrm{Yb}$ & ppm & 0.1 & AR-MS & 1.4 & 1.3 & 1.2 & 1.2 & 1.3 & 1.3 & 1.3 & 1.3 & 1.5 \\
\hline $\mathrm{Au}$ & $\mathrm{ppb}$ & 0.5 & AR-MS & 1.5 & 1.9 & 0.5 & 0.9 & 0.7 & 0.7 & 0.5 & 0.001 & 9.4 \\
\hline $\mathrm{Tl}$ & ppm & 0.02 & AR-MS & 0.26 & 0.26 & 0.2 & 0.2 & 0.22 & 0.23 & 0.26 & 0.0 & 0.27 \\
\hline $\mathrm{Pb}$ & ppm & 0.01 & AR-MS & 19 & 17.9 & 16.8 & 16.4 & 17.9 & 18.3 & 17.7 & 0.24 & 17.3 \\
\hline $\mathrm{Bi}$ & ppm & 0.02 & AR-MS & 0.23 & 0.2 & 0.18 & 0.19 & 0.19 & 0.19 & 0.18 & 17.3 & 0.17 \\
\hline Th & ppm & 0.1 & AR-MS & 10.7 & 9.4 & 8.8 & 9.0 & 9.5 & 9.3 & 9.5 & 0.16 & 8.8 \\
\hline $\mathrm{U}$ & ppm & 0.1 & AR-MS & 1.8 & 2.1 & 2.3 & 1.7 & 1.9 & 2.0 & 1.6 & 8.2 & 0.9 \\
\hline
\end{tabular}

\section{RESULTS AND DISCUSSION}

The chemical compositions of the ice-dammed lake clays of the Lębork deposit showed that the dominant component of the clays is $\mathrm{SiO}_{2}$ (Table 2). The mean $\mathrm{SiO}_{2}$ content for the entire deposit is $56.13 \mathrm{wt}$ \%, with a maximum of $60.74 \mathrm{wt} . \%$ for the middle part of the profile from location 1 , and a minimum of $51.47 \mathrm{wt} . \%$ in the uppermost part of the profile at location 2. The standard deviation of the $\mathrm{SiO}_{2}$ content is 3.27 wt.\% (Table 3 ). The second most abundant component is $\mathrm{Al}_{2} \mathrm{O}_{3}$ (Table 2), with a mean content throughout the entire deposit of $11.61 \mathrm{wt} \%$, which has a maximum value of $12.56 \mathrm{wt} \%$ in the middle part of the profile of location 3 , and a minimum content of $10.41 \mathrm{wt} \%$ in the middle of the profile of location 2 . The small standard deviation is noteworthy, just 0.72 wt.\% for $\mathrm{Al}_{2} \mathrm{O}_{3}$ (Table 3.). The next most abundant component in terms of content in the analysed deposit is $\mathrm{CaO}$ (Table 2). The arithmetic mean $\mathrm{CaO}$ content for the entire deposit is $8.32 \mathrm{wt} . \%$, with a maximum of $9.82 \mathrm{wt} . \%$ in the bottom of the location 2 profile and minimum of 6.11 wt.\% in the top of the location 1 profile. The standard deviation of the $\mathrm{CaO}$ content was 1.20 wt.\% (Table 3 ). The amount of $\mathrm{Fe}$ compounds in the analysed deposits is also noteworthy. The analysis for $\mathrm{Fe}(\mathrm{III})$ oxide $\left(\mathrm{Fe}_{2} \mathrm{O}_{3}\right)$ showed a mean arithmetic content in the deposit of 5.33 wt.\% (Table 3). The maximum of $6.42 \mathrm{wt} \%$ was found in the uppermost part of the location 2 profile, and a minimum of $4.54 \mathrm{wt} \%$ in the bottom part of the location 2 profile (Table 2). The very small standard deviation of $\mathrm{Fe}_{2} \mathrm{O}_{3}$ content, of $0.68 \mathrm{wt}$. $\%$ for the entire deposit, is also significant.

Magnesium and potassium are expressed as oxides because of the aforementioned process of ignition of samples. The occurrence of $\mathrm{Mg}$ may be related either to the presence in the moraine till of the Gardno phase of Paleozoic dolomites found by Nowacka and Neumann (2008), and/or to processes of weathering of aluminosilicates.

For the purposes of statistical calculations (Table 4), a matrix of correlation coefficients was applied to describe relationships between the main chemical compounds of the deposits analysed. Significant correlations $(>|0.7|)$ are highlighted in red.

A strong positive correlation was associated with $\mathrm{Al}_{2} \mathrm{O}_{3}$, $\mathrm{Fe}_{2} \mathrm{O}_{3}$, and $\mathrm{K}_{2} \mathrm{O}$. $\mathrm{TiO}_{2}$ had a strong positive correlation with $\mathrm{Fe}_{2} \mathrm{O}_{3}$, and $\mathrm{MgO}$ with $\mathrm{CaO}$, while both $\mathrm{CaO}$ and $\mathrm{MgO}$ showed a strong negative correlation with $\mathrm{SiO}_{2}$. A strong negative correlation was also evident between $\mathrm{Na}_{2} \mathrm{O}$ and $\mathrm{Al}_{2} \mathrm{O}_{3}$.

The uncommon occurrences of rare earth elements (REE) such as cerium, neodymium, lanthanum, and praseodymium were also observed (Table 5). The mean contents were 56.9, 27.0, 26.3, and 7.3 ppm, respectively, which are in accord with the average contents of such elements in clayey deposits worldwide according to Kabata-Pendias and Mukherjee (2007) (Table 7).

In accordance with the methodology of processing results of geochemical analyses, linear Pearson correlation analysis was performed (Table 6). This provided the basis for the division of the study material in terms of genesis and composition of rock material, as well as characteristics of the processes of weathering and transport.

Small lateral and vertical variability in mineralogical composition and the amounts of trace elements present suggest continuous sedimentation and consistent sediment supply. The sedimentation process itself probably occurred slowly and the material was supplied from suspension currents, with no evident catastrophic episodes such as rapid temperature changes, landslides, etc. Some variability in $\mathrm{SiO}_{2}$ content was noted (vertically and laterally: Fig. 6), possibly caused by variability in quartz abundance, especially in light (silty) laminae.

The general chemical composition of ice-dammed lake clays from Lębork is very close to that of varved clays from Opaleń, located $\sim 110 \mathrm{~km}$ to the southeast, dated to the Mazovian II interglacial or Varsovian insterstadial (Domański 1961).

Literature relating to $\mathrm{Ca}$ content in sedimentary rocks has shown that $\mathrm{Ca}$ in the Lębork could have originated both from 
Table 6 Statistical parameters of the chemical analyses

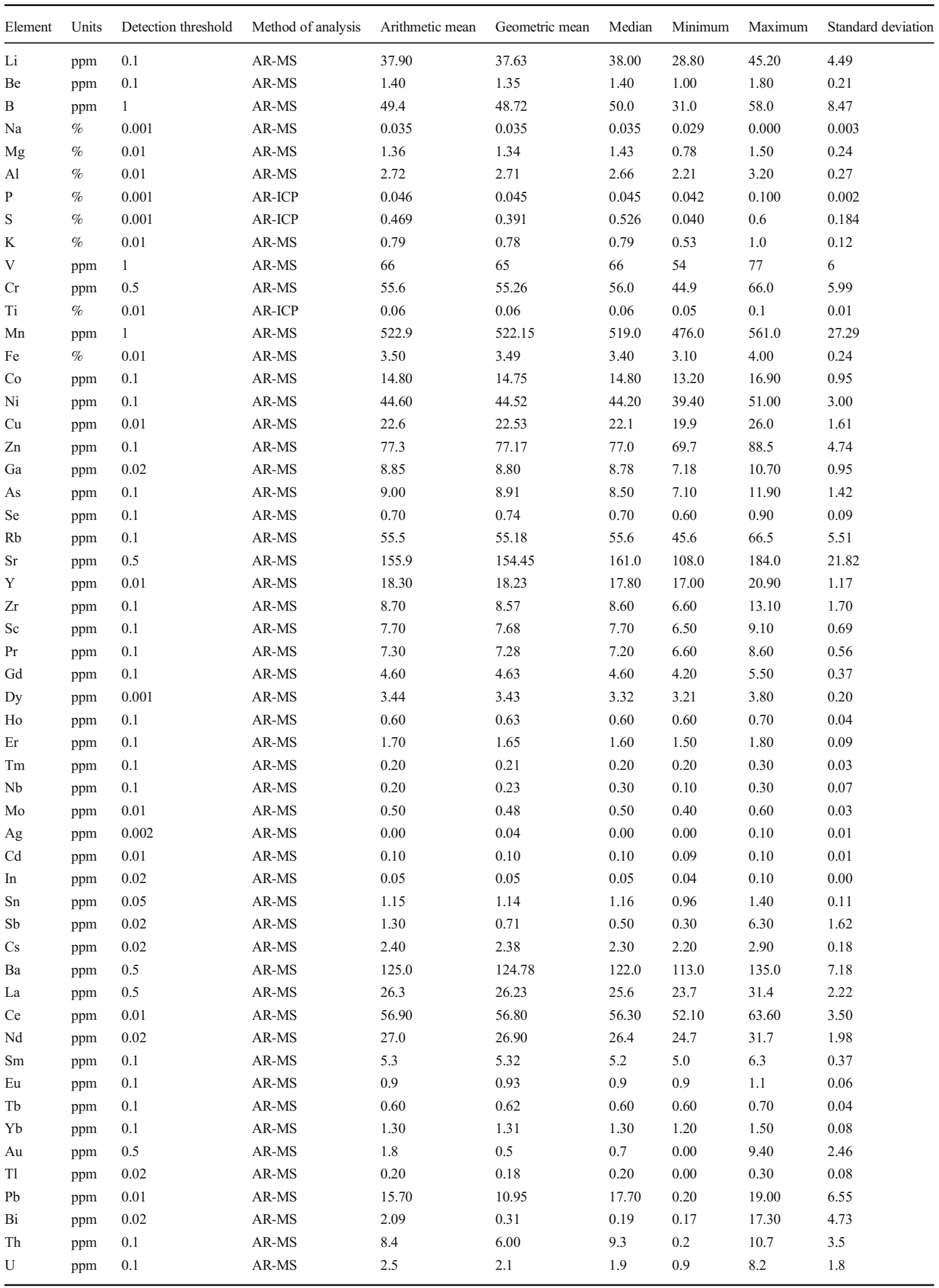


Table 7 Average REE contents in igneous and sedimentary rocks; data for clays are indicated in bold (source: Kabata-Pendias and Mukherjee 2007)

\begin{tabular}{|c|c|c|c|c|c|}
\hline \multirow[t]{2}{*}{ REE } & \multicolumn{2}{|c|}{ Igneous rocks (mg/kg) } & \multicolumn{3}{|c|}{ Sedimentary rocks $(\mathrm{mg} / \mathrm{kg})$} \\
\hline & alkaline & acidic & clays & sandstones & limestones \\
\hline Lanthanum & $2-70$ & $30-150$ & 30-90 & $17-40$ & $4-10$ \\
\hline Cerium & $4-60$ & $80-250$ & $3-90$ & $25-80$ & $7-20$ \\
\hline Praseodymium & $1-15$ & $6-30$ & 6-10 & $4-9$ & $1-2.5$ \\
\hline Neodymium & $2-30$ & $18-80$ & 18-35 & $16-48$ & $5-9$ \\
\hline Samarium & $0.1-1.7$ & $6-11$ & $5-7$ & $4-10$ & $1-2$ \\
\hline Europium & $0.01-4$ & $1-2$ & $1-2$ & $0.7-2$ & $0.2-0.4$ \\
\hline Gadolinium & $0.1-8$ & $4-10$ & $5-7.5$ & $3-10$ & $1.3-2.7$ \\
\hline Terbium & $0.1-1.2$ & $1-1.25$ & $0.9-1.1$ & $1.6-2$ & $0.2-0.4$ \\
\hline Dysprosium & $0.05-7$ & $5-8$ & $4-6$ & $2.6-7.2$ & $0.8-2$ \\
\hline Holmium & $0.1-1.5$ & $1.3-2$ & 1-1.8 & $0.05-2$ & $0.2-0.3$ \\
\hline Erbium & $0.1-1$ & $3.4-0.7$ & $2.5-4$ & $1.5-6$ & $0.4-1.7$ \\
\hline Thulium & $0.1-0.6$ & $0.3-0.7$ & $0.2-0.6$ & 0.3 & $0.03-0.2$ \\
\hline Ytterbium & $0.1-3.5$ & $3-4.5$ & $2.2-4$ & $1.2-4.4$ & $0.3-1.6$ \\
\hline Lutetium & $0.1-0.6$ & $0.5-1.2$ & $0.2-0.7$ & $0.8-1.2$ & $0.03-0.2$ \\
\hline
\end{tabular}

the weathering of plagioclase (Na-Ca feldspars) from Scandinavian crystalline rocks, and/or from Scandinavian Paleozoic limestones, the occurrence of which was determined in the moraine till of the Gardno phase (Nowacka and Neumann 2008).

Variability in the chemical composition of ice-dammed lake clays in the Lębork ice-dammed lake deposits profile is considerably less prominent than that in the vertical profile of the ice-dammed lake clays from Opalenie (Domański 1961). In the latter, the variability of $\mathrm{SiO}_{2}$ content reaches as much as $25 \mathrm{wt} . \%$, and varved clays of the Lębork ice-dammed lake are very different from the clays from Poznań, showing variations in terms of elements found, depending on the region of deposition (Bojakowska et al. 2010).
The occurrence of Cretaceous and Paleogene dinoflagellate cysts showed that sediments of these ages could also be reworked and redeposited as varved clays at Lębork. This may confirm a Tertiary origin of the quartz grains in the varves of the Lębork ice-dammed lake (Gedl 2011).

\section{Mineralogical Composition of Ice-dammed Lake Clay}

The mineralogical composition, determined by XRD, showed that the primary minerals of the deposits analysed include quartz, muscovite, calcite, and the clay minerals illite, kaolinite, and montmorillonite. Illite and chlorite are the main components, and are products of weathering of crystalline and metamorphic rocks (Fig. 5)

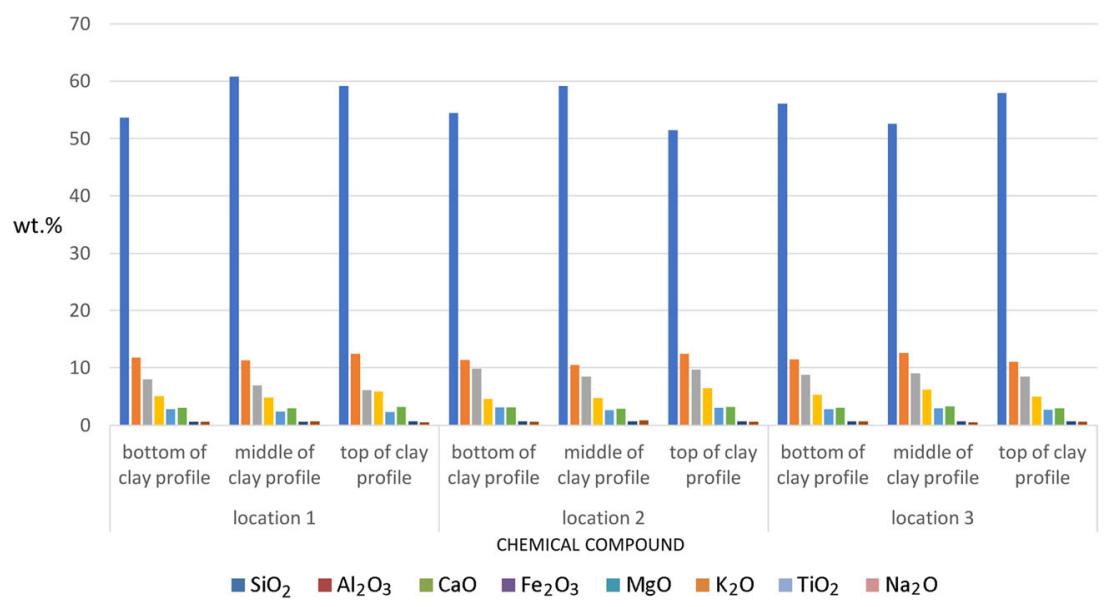

Fig. 6 Chemical composition of ice-dammed lake clays from the Lębork deposits 


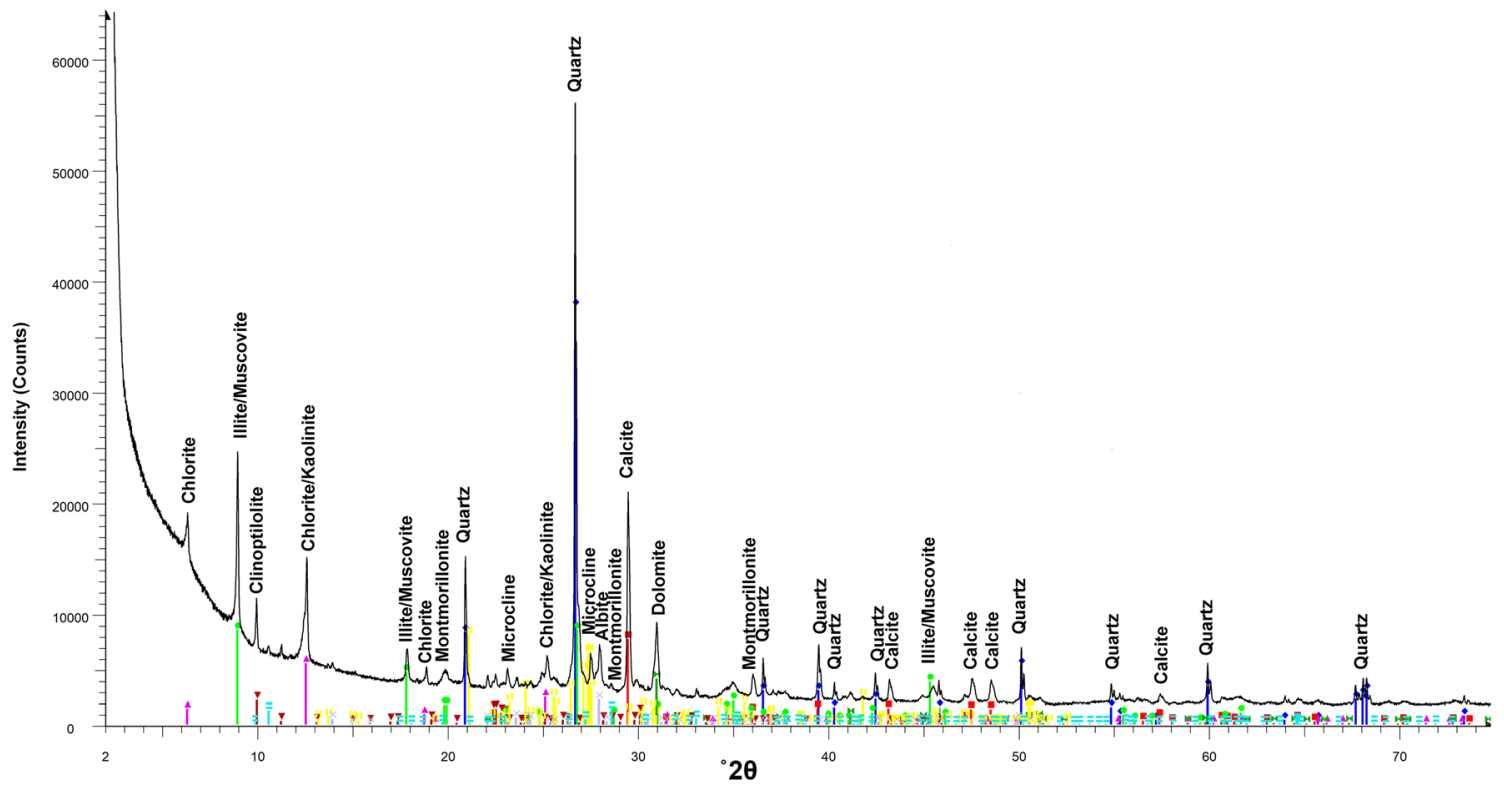

Fig. 7 XRD pattern of a sample of ice-dammed lake deposits from the uppermost part of the deposit from location 3

(Millot 1970), but can also form during diagenesis of clay-rich sediments (Środoń 1996). Smectite illitization is another common mineralogical reaction occurring during the burial diagenesis of clay-rich sediments (Lanson et al. 2009).

The XRD analyses confirmed the small variability of the chemical and mineralogical composition of sediments from the Lębork deposit, demonstrated above by other means (Figs. 7, 8).

Supplementary Material Table S1 includes the matrix of correlations for elements determined in the Lębork deposit.

\section{CONCLUSIONS}

The mineralogical composition of ice-dammed lake clays is typical of clayey rocks. The material filling the Lębork basin is characterized by little lateral and vertical variability in terms of chemical composition. This suggests continuous sedimentation and consistent sediment supply over the $\sim 2000 \mathrm{y}$ of existence of the ice-dammed lake. These results are quite different from the varved clays at Opalen and at Poznań, where greater variability in mineralogical composition and of specific elements was observed, depending on the region of deposition.

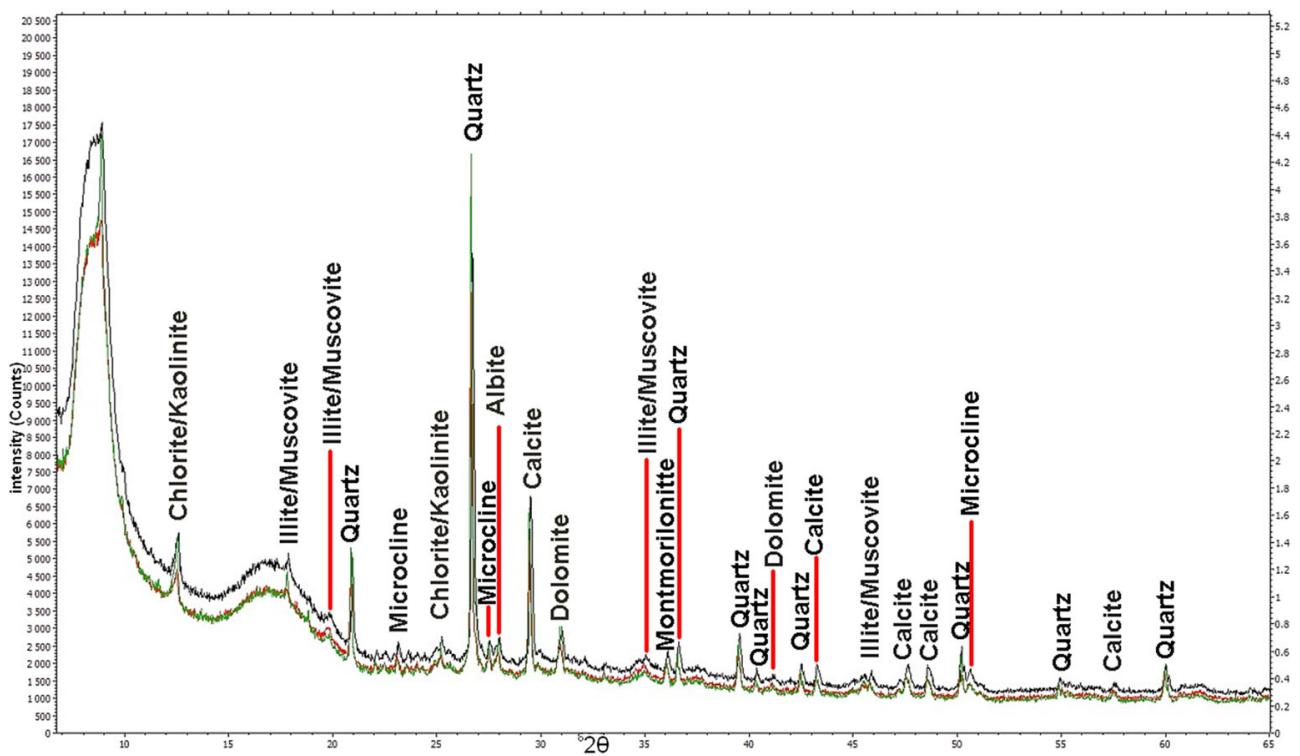

Fig. 8 XRD patterns of samples from location 1: the bottom (black), middle (red) and top (green) 
The chemical composition of ice-dammed lake clays showed average contents of elements or chemical compounds likely to constitute a potential threat to the environment during or after potential reclamation of the excavation wall.

\section{Declarations}

\section{Conflict of Interest}

The authors declare that they have no conflict of interest.

\section{REFERENCES}

Antevs, E. (1951). Glacial clays in Steep Rock Lake, Ontario, Canada. Geological Society of America Bulletin, 62, 1223-1262.

Bakhmutov, V. G., Yevzerov, V. Y., \& Kolka, V. V. (2008). Varved clay paleomagnetism: sedimentogenesis and secular variation record. Izvestiya, Physics of the Solid Earth, 45, 567-582.

Bojakowska, I., Brański, P., Iwasińska-Budzyk, I., \& Retka, J. (2010). Variability of the content of trace elements in Poznań series clays. Mining and Geology, 5, 31-40.

De Geer, G. (1912). A geochronology of the last 12000 years. Compt. Rend. 11e Congr. Géol. Internat., Stockholm, v. 1, p. 241-253. (reprinted 1975. Glacial Deposits, 21, 432-440 in: Benchmark Papers in Geology (R. P. Goldthwait, editor). Dowden Hutchinson and Ross, Stroudsburg, Pennsylvania, USA.)

Domański, J. (1961). Some petrographic properties of varved clays from Opalenie near Tczew (Northern Poland). Annales Societatis Geologorum Poloniae, 31, 335-355.

Gedl, P. (2011). Palynology of Late Pleistocene varved clays from icedammed lakes at Lębork and Złocieniec (north-western Poland) preliminary results. Geologos, 17, 49-59.

Kabata-Pendias, A. \& Mukherjee, A. B. (2007). Trace Elements from Soil to Human. Springer. 576 pp.

Karnkowski, H. (1993). Cyclicality of sedimentation - cyclic sedimentation - sedimentary cycles. Przeglad Geologiczny, 41, 323-326.

Kondracki, J. (2000). Regional Geography of Poland. Polish Scientific Publishers PWN, Warsaw (in Polish).

Krygowski, B. (1934). Varved clays from the vicinity of Poznań. Badania Geograficzne, Prace Instytutu Geograficznego Uniwersytetu Poznańskiego wydawane pod kierunkiem profesora geografji Stanisława Pawtowskiego, Poznań, 8, 1-43.

Kuenen, P. H. (1951). Mechanics of varve formation and the action of turbidity currents. Geologiska Föreningen i Stockholm Förhandlingar, 73, 69-84.

Lanson, B., Sakharov, B., Claret, F., \& Drits, V. (2009). Diagenetic smectite-to-illite transition in clay-rich sediments: A reappraisal of $\mathrm{X}$-ray diffraction results using the multi-specimen method. American Journal of Science, 309, 476-516.
Marks, L. (2005). Pleistocene glacial limits in the territory of Poland. Przeglad Geologiczny, 53, 988-993.

Merta, T. (1978). Extraglacial varved deposits of the Warsaw icedammed lake (Younger Pleistocene), Mazovian Lowland, Central Poland. Acta Geologica Polonica, 28, 241-272.

Millot, G. (1970). Geology of Clays: Weathering · Sedimentology · Geochemistry. Springer, $443 \mathrm{pp}$.

Morawski, W. (1989). Morphogenesis of the Lebsko Lowland and Leba ice-marginal valley between Lębork and Leba. Studia $i$ Materiaty Oceanologiczne, 56, 163-170.

Morawski, W. (1990). Explanations to the detailed geological map of Poland - sheet 12 Lębork. Wydawnictwa Geologiczne.

Morawski, W. (1991). Sedimentation of fluviomorainic sediments at subsequent stages of deglaciation of the western part of the Lębork Plateau. Pp. 127-242 in: Genesis, Lithology and Stratigraphy of Quaternary Formations (A. Kostrzewski, editor). UAM, Geografia, 50.

Nowacka, N., \& Neumann, M. (2008). The petrographical diversity of the glacial deposits in the Gardno marginal. Prace Geograficzne, 120, 93-104.

Paluszkiewicz, R. (2004). Conditions of sedimentation of rhythmically stratified sediments in the Złocieniecki ice-dammed lake in the Drawskie Lakeland. The Poznan Society for the Advancement of the Arts and Sciences Prace Komisji Geograficzno Geologicznej, $34,1-101$.

Peterss, K. (1995). Fabric analyses of Pomeranian and Late-glacial tills in Macklenburg. In: Glacial deposits in North-East Europe (J. Ehlers, S. Kozarski and P. Gibbard, editors). AA. Balkema.

Piątkowski, J. (1960). Łeba ice-marginal valley, Łeba Spit, and Lębork ice-dammed lake. Annales Societatis Geologorum Poloniae, 29, 375-386.

Richling, A. \& Ostaszewska, K. (2005). Physical Geography of Poland. Wydawnictwo. Naukowe PWN, Warszawa, 345 pp.

Środoń, J. (1996). Clay minerals in diagenetic processes. Przeglad Geologiczny, 44, 604-607.

Stroeven, A. P., Hättestrand, C., Kleman, J., Heyman, J., Fabel, D., Fredin, O., Goodfellow, B. W., Harbor, J. M., Jansen, J. D., Olsen, L., Caffee, M. W., Fink, D., Lundqvist, J., Rosqvist, G. C., Strömberg, B., \& Jansson, K. N. (2016). Deglaciation of Fennoscandia. Quaternary Science Reviews, 147, 91-121.

Sturm, M. (1979). Origin and composition of clastic varves. Pp. 281285 in: Moraines and Varves: Origin, Genesis, Classification (C. Schluter, editor). A. A. Balkema.

Vyahirev, S. (1997). Structural characteristics of varved clays as the manifestation of different-order depositional cyclicity. Examples from Karelia. Geological Survey of Finland, Special Paper, 24, $67-74$.

Zaleszkiewicz, L. (2005). Explanations to the detailed geological map of Poland - sheet 13 Eeczyce, Wydawnictwa Państwowego Instytutu Geologicznego, Warszawa.

(Received 6 August 2020; revised 7 April 2021; AE: Warren D. Huff) 